\title{
PENGEMBANGAN MULTIMEDIA PEMBELAJARAN GEOGRAFI BERBENTUK MAJALAH ELEKTRONIK DENGAN MATERI HIDROSFER UNTUK SISWA SMA KELAS
}

$\mathbf{X}$

\section{DEVELOPING GEOGRAPHY INSTRUCTIONAL MULTIMEDIA IN THE FORM OF AN ELECTRONIC MAGAZINE WITH HYDROSPHERE MATERIAL FOR HIGH SCHOOL STUDENTS OF CLASS X}

\author{
Dian Ardhina ${ }^{1}$, Mukminan ${ }^{2}$ \\ ${ }^{1}$ Pendidikan Ilmu Pengetahuan Sosial PPS ${ }^{2}$ Universitas Negeri Yogyakarta \\ D_Ardhina@yahoo.com, Mukminan@yahoo.co.id
}

\begin{abstract}
Abstrak
Penelitian ini bertujuan untuk menghasilkan multimedia pembelajaran geografi berbentuk majalah elektronik dengan materi hidrosfer yang layak dan efektif untuk siswa SMA kelas X. Penelitian ini merupakan jenis penelitian dan pengembangan (research and development) yang mengacu pada model pengembangaan Alessi \& Trollip yang meliputi tiga tahapan yaitu tahap perencanaan, tahap desain, dan tahap pengembangan. Setelah melalui tahap pengembangan awal dihasilkan produk awal multimedia. Tahap selanjutnya dilakukan evaluasi formatif untuk mengetahui kelayakan produk yang terdiri atas Alpha Test, Beta Test I, dan Beta Test II. Pada tahap akhir produk dilakukan evaluasi sumatif untuk mengetahui keefektifan produk berupa skor tes hasil belajar. Hasil penelitian ini adalah: (1) Multimedia pembelajaran geografi berbentuk majalah elektronik yang dikembangkan layak digunakan sebagai sumber belajar berdasarkan validasi dari ahli materi, validasi dari ahli media, validasi dari guru geografi SMA kelas X, uji coba beta test I, dan uji coba beta test II. (2) Multimedia pembelajaran geografi berbentuk majalah elektronik dengan materi hidrosfer untuk siswa SMA kelas $\mathrm{X}$ yang dikembangkan efektif dan dapat meningkatkan penguasaan kompetensi mata pelajaran geografi, dibuktikan dengan peningkatan nilai hasil belajar siswa.
\end{abstract}

Kata Kunci: multimedia pembelajaran geografi, majalah elektronik, keefektifan multimedia.

\begin{abstract}
This study aims to produce geography instructional multimedia in the form of an electronic magazine with hydrosphere material the viable and effective for high school students of class $X$. This was a research and development study which is based on Alessi \& Trollip development model which has three primary stages, i. e. the planning, design, and the development stage. After the preliminary development stage, a preliminary product multimedia was produced, and in the next stage, formative test to investigate the product feasible, consisting of Alpha Test, Beta Test I, and Beta Test II, were conducted. In the final product stage, a summative evaluation was carried out to investigate the product effectiveness in the form of course competence mastery represented by the score of the learning achievement test. The results of the study are as follows: (1) the geography instructional multimedia in the form of an electronic magazine was considered feasible as a source of learning, from materials expert assessment, media experts assessment, the assessment of high school geography teacher, the beta test I, and the beta test II. (2) The developed geography instructional multimedia in the form of an electronic magazine with hydrosphere materials for high school students of class $X$ is effective and capable of improving the competence mastery in the course of geography subjects, evidenced by the increase in students learning outcomes
\end{abstract}

Keywords: geography instructional multimedia, electronic magazine, multimedia effectiveness. 


\section{Pendahuluan}

Pendidikan adalah suatu usaha atau kegiatan yang dijalankan dengan sengaja, teratur dan berencana dengan maksud mengubah atau mengembangkan perilaku yang diinginkan. Guru harus mampu (kompeten) menciptakan suasana pembelajaran yang kondusif untuk mencapai tujuan dan misi pendidikan nasional. Oleh karena itu, guru dituntut untuk lebih profesional, inovatif, perspektif, dan proaktif dalam melaksanakan tugasnya. Menurut Gagne \& Briggs (1979, p. 19)

"Instruction is the means employed by teachers, designers of materials curriculum specialists and where revers where purpuse it is to develop an organized plan to promote learning".

Pembelajaran yang baik dapat ditunjang dari suasana pembelajaran yang kondusif serta hubungan komunikasi antara guru dan siswa dapat berjalan dengan baik. Guru sebagai fasilitator, mediator dan pembimbing dalam pembelajaran dapat membantu proses perubahan pengetahuan siswa.

Geografi sebagai teori tentang ruang bumi (earth space theory), membahas tentang adaptasi keruangan manusia dalam berperilaku secara spatial, misalnya kota-kota yang semakin padat penduduknya (Daldjoeni, 2014, p. 30). Sumaatmadja (2001, p. 21) menjelaskan ruang lingkup pembelajaran geografi meliputi: (1) Alam lingkungan yang menjadi sumber daya bagi umat manusia, (2) Penyebaran umat manusia, (3) Interaksi keruangan umat manusia dengan alam lingkungan yang memberikan variasi terhadap ciri khas tempat-tempat dipermukaan bumi, dan (4) Kesatuan regional yang merupakan permaduan matra darat, air dan udara.

Di sekolah, geografi merupakan salah satu mata pelajaran yang harus dikuasai semua siswa kelas $\mathrm{X}$ terlebih siswa yang memilih jurusan Peminatan Ilmu Sosial (IS). Banyaknya materi pembelajaran pada pelajaran geografi terutama pada materi pokok hidrosfer yang harus diselesaikan dalam waktu tertentu menjadikan pembelajaran hanya menargetkan pada ketuntasan materi.

Perkembangan teknologi dan informasi yang sangat pesat mendorong adanya inovasi dalam proses kegiatan pembelajaran untuk meningkatkan efektivitas dan fleksibilitas pembelajaran. Komputer mampu menampilkan berbagai komponen media yang disebut dengan multimedia seperti video, gambar, teks, animasi, dan suara sehingga dapat merangsang lebih banyak indera. Mayer (2001, p. 2) menjelaskan:

"...Multimedia as the presentation of material using both words and pictures. By words, the material is presented in verbal form, such as using printed or spoken text. By pictures, the material is presented in pictorial form, such as using static graphics, including illustrations, graphs, photos, or maps, or using dynamic graphics, including animation or video".

Multimedia dapat menampilkan hal atau kejadian nyata yang berkaitan dengan materi yang dipelajari sehingga pembelajaran menjadi lebih kontekstual dan siswa lebih mudah memahami materi.

Alessi \& Trollip (2001, p. 410) menjelaskan model pengembangan multimedia pembelajaran memiliki tiga atribut yaitu standards, ongoing evaluation dan project management. Ketiga atribut ini melekat pada tiga tahap, yakni planning, design dan development. Standards meliputi penetapan standar kualitas produk yang akan dibuat. Ongoing evaluation adalah evaluasi yang melekat pada awal, tengah, atau akhir pengembangan produk. Evaluasi ini bersifat tidak formal dan dilakukan pada saat proses pengembangan masih berlangsung. Project management merupakan bagian dan proses penyelesaian terhadap perencanaan yang akan dilakukan, memonitoring secara konstan terhadap kemajuan pelaksanaan tiga tahap pengembangan (planning, design, dan development). Evaluasi multimedia pembelajaran dapat dilakukan melalui: pertama, evaluasi formatif, terdiri atas ongoing evaluation, alpha testing, dan beta testing. Kedua, evaluasi sumatif/uji efektivitas.

Munir (2013, p. 156) menjelaskan prinsipprinsip pembuatan multimedia pembelajaran, yaitu: (1) mudah mendapatkan bahan bakunya, (2) murah bahan bakunya sehingga terjangkau oleh peserta didik, pendidik, atau sekolah untuk menyediakannya dan membuatnya, (3) multiguna atau manfaatnya banyak, (4) menimbulkan kreativitas peserta 
didik, (5) dapat menarik perhatian peserta didik, (6) menggunakan bahan yang tidak membahayakan bagi peserta didik atau pendidik, (7) menggunakan multimedia pembelajaran tersebut bisa secara individual, kelompok, atau klasikal, dan (8) menyesuaikan dengan tingkat perkembangan peserta didik, baik fisik, mental, atau pikirannya.

Sutopo (2003, p. 21) mengungkapkan bahwa sistem multimedia mempunyai beberapa keuntungan, yaitu: (1) mengurangi waktu dan ruang yang digunakan untuk menyimpan dan menampilkan dokumen dalam bentuk elektronik dibanding dalam bentuk kertas, (2) meningkatkan produktivitas dengan menghindari file, (3) memberi akses dokumen dalam waktu yang bersamaan dan ditampilkan dalam layar, (4) memberi informasi multidimensi dalam organisasi, (5) mengurangi waktu dan biaya dalam pembuatan foto, dan (6) memberikan fasilitas kecepatan informasi yang diperlukan dengan interaksi visual.

Dipilihnya multimedia pembelajaran diharapkan mampu membantu mengatasi permasalahan-permasalahan yang ada dalam proses pembelajaran seperti keterbatasan waktu dalam menyampaikan materi. Pemanfaatan multimedia pembelajaran tidak hanya bersifat sekedar suplemen atau bagian yang tidak bermakna dalam pembelajaran namun pemanfaatan multimedia diharapkan mampu memberdayakan siswa, yaitu mendorong tumbuhnya keterampilan belajar mandiri, keterampilan bernalar, mampu meningkatkan keaktifan siswa, dan juga keterampilan memanfaatkan berbagai sumber belajar.

Berdasarkan penelitian oleh Kingsley \& Boone (2009) yang berjudul "Effects of multimedia software on achievement of middle school students in a America History class" menunjukkan pengaruh positif secara statistik signifikan pada nilai prestasi keseluruhan untuk siswa yang menggunakan perangkat lunak (multimedia). Rata-rata nilai tes bagi siswa yang menggunakan perangkat lunak ditingkatkan sampai $12,2 \%$ dan rata-rata sebesar 6,09 jawaban benar dari pretest ke posttest. Sedangkan skor rata-rata untuk siswa kelompok kontrol meningkat sebesar $6,1 \%$ rata-rata sebesar 3,06 jawaban benar meningkat dari pretest ke posttest.
Penelitian oleh Murwantono \& Sukidjo (2015) yang berjudul "Peningkatan hasil belajar IPS dengan model problem based learning berbantuan media stimulan bergambar" menjelaskan bahwa penggunaan pembelajaran model problem based learning berbantuan media stimultan gambar dalam proses pembelajaran dapat: (1) meningkatkan kualitas pembelajaran, sikap sosial, minat, dan aktivitas siswa dalam pembelajaran ilmu pengetahuan sosial; (2) meningkatkan hasil belajar; (3) cocok digunakan dalam pembelajaran IPS terpadu yang dapat melibatkan siswa secara aktif dalam proses pembelajaran; (4) dapat meningkatkan sikap, minat, aktivitas, dan hasil belajar siswa.

Saat ini, guru sudah mulai menggunakan media elektronik sebagai media pembelajaran di kelas. Media pembelajaran yang digunakan masih dalam bentuk powerpoint karena dianggap lebih mudah dan praktis untuk digunakan. Multimedia pembelajaran geografi berbentuk majalah elektronik masih belum banyak dikembangkan oleh guru, sehingga belum diketahui kelayakan dan keefektifannya sebagai sumber belajar.

Fungsi majalah dalam dunia pendidikan yaitu: (1) Membangkitkan motivasi membaca, karena majalah mengandung bahan bacaan yang hangat, aktual, dan memuat data terakhir tentang hal yang menarik perhatian, (2) Majalah sebagai bahan diskusi siswa dengan topik yang berkaitan dengan materi pelajaran, (3) Memperkaya perbendaharaan pengetahuan, dan (4) Membangkitkan kemampuan berpikir kritis (Daryanto, 2010, p. 25).

Multimedia pembelajaran geografi berbentuk majalah elektronik termasuk dalam multimedia pembelajaran berbasis komputer. Majalah elektronik tidak hanya menyajikan materi yang dapat dilihat dan dibaca tetapi juga menyajikan video yang dapat dilihat dan didengar. Penggunaan alat dan bahan ajaran khusus untuk komunikasi, seperti majalah elektronik memiliki keuntungan yaitu dapat membantu secara konkret konsep berpikir dan mengurangi respons yang kurang bermanfaat. Selain itu, majalah elektronik juga dapat menambah frekuensi belajar siswa karena penggunaannya mudah, sehingga siswa dapat belajar lebih mendalam mengenai materi yang dipelajari.

Manfaat penelitian pengembangan ini adalah: (1) Menjelaskan tentang kelayakan 
dan keefektifan multimedia pembelajaran geografi berbentuk majalah elektronik sebagai sumber belajar, (2) Memprediksi penguasaan kompetensi mata pelajaran geografi yang terjadi menggunakan multimedia pembelajaran geografi berbentuk majalah elektronik, dan (3) Mengontrol penguasaan kompetensi mata pelajaran geografi bila menggunakan multimedia pembelajaran geografi berbentuk majalah eleltronik.

Spesifikasi produk yang dikembangkan dalam penelitian ini adalah: (1) Sesuai dengan materi pokok hidrosfer, (2) Penyajian dalam multimedia pembelajaran geografi berbentuk majalah elektronik yang isinya meliputi materi hidrosfer, (3) Multimedia pembelajaran geografi berbentuk majalah elektronik disajikan dengan tampilan yang menarik dan dilengkapi dengan gambar dan video yang sesuai dengan materi, dan (4) Dapat digunakan sebagai sumber belajar di kelas dan untuk belajar mandiri.

Asumsi dalam pengembangan multimedia pembelajaran geografi berbentuk majalah elektronik ini adalah: (1) Multimedia pembelajaran geografi berbentuk majalah elektronik yang disusun dapat menjadi bahan bacaan yang menarik dan sebagai sumber belajar alternatif bagi siswa selain buku teks pelajaran geografi. dan (2) Multimedia pembelajaran geografi berbentuk majalah elektronik disajikan dengan bahasa yang ringan, gambar dan video untuk memperjelas materi sehingga siswa cepat memahami isi materi.

\section{Metode Penelitian}

\section{Jenis dan Desain Penelitian}

Penelitian ini merupakan jenis penelitian dan pengembangan (Research and Development), yang menghasilkan produk pembelajaran berupa multimedia pembelajaran geografi berbentuk majalah elektronik dengan materi hidrosfer untuk siswa SMA kelas X.

Model desain pengembangan yang digunakan pada penelitian dan pengembangan ini merupakan adaptasi langkah-langkah model pengembangan Alessi \& Trollip (2001, p. 490) yang mempunyai tiga atribut (three attributes) dan tiga fase (three phases). Tiga atribut tersebut adalah standards, ongoing evaluation, dan project management, sedangkan tiga fasenya adalah planning, design, dan development. Evaluasi multimedia dilakukan sesuai dengan langkah-langkah evaluasi yang terdiri dari evaluasi formatif dan evaluasi sumatif.

Evaluasi formatif terdiri atas ongoing evaluation, alpha testing dan beta testing. Evaluasi sumatif dilakukan setelah program selesai dievaluasi secara formatif dan direvisi sesuai dengan standar yang digunakan oleh pengembang. Evaluasi sumatif dilakukan untuk mengetahui efektivitas atau fungsi produk atau program akhir multimedia pembelajaran dalam bentuk pencapaian hasil belajar.

\section{Waktu dan Tempat Penelitian}

Penelitian ini dilaksanakan pada bulan Mei 2015 di Laboratorium Komputer SMA Negeri 1 Pundong.

\section{Target/Subjek Penelitian}

Subjek uji coba penelitian ini adalah siswa SMA kelas X SMA Negeri 1 Pundong. Jumlah subjek uji coba sebanyak 58 siswa dengan perincian: 7 siswa untuk uji coba beta test $I, 25$ siswa untuk uji coba beta test II, dan 26 siswa untuk uji efektivitas multimedia.

\section{Prosedur Pengembangan}

Prosedur penelitian ini menggunakan model penelitian pengembangan yang merupakan adaptasi dari model Alessi \& Trollip (2001, p. 410). Prosedur desain pengembangan dalam penelitian ini dibagi dalam tiga atribut yaitu standards, ongoing evaluation, dan project management serta tiga fase yang meliputi planning, design, dan development.

Prosedur pengembangan secara sederhana akan diuraikan sebagai berkut: Pertama, tahap perencanaan, meliputi: (a) Mendefinisikan ruang lingkup, (b) Mengidentifikasi karakteristik siswa, (c) Keterbatasan produk, (d) Membuat dokumen pengelolaan waktu, (e) Membuat project standards manual, (f) Menentukan dan mengumpulkan sumber-sumber, (g) Melakukan curah pendapat (brainstorming), (h) Menggambarkan tampilan dan nuansa, (i) Menyiapkan naskah, dan (j) Mendapat persetujuan. 
Kedua, tahap desain, meliputi: (a) Mengembangkan ide, (b) Analisis tugas dan konsep, (c) Deskripsi program, (d) Menyiapkan prototype dan menyiapkan materi yang dibutuhkan, (e) Menyiapkan flowchart dan storyboard multimedia, (f) Menyiapkan naskah, dan (g) Mendapat persetujuan

Ketiga, tahap pengembangan, meliputi: (a) Menyiapkan teks produksi, (b) Menulis kode program, (c) Membuat grafis, (d) Memproduksi audio dan video, (e) Menggabungkan bagian, (f) Menyiapakan bahan pendukung, (g) Alpha test, (h) Revisi alpha test, (i) Beta test, (j) Mendapatkan persetujuan, dan (k) Evaluasi sumatif

Data, Instrumen, dan Teknik Pengumpulan Data

Data

Data primer yang dikumpulkan adalah data hasil validasi dari ahli materi, data hasil validasi dari ahli media, data hasil validasi dari guru geografi SMA kelas X, data hasil uji coba oleh siswa SMA kelas X, dan data hasil belajar geografi dengan tes pilihan ganda. Pertanyaan dalam tes pilihan ganda terkait dengan materi hidrosfer.

\section{Instrumen}

Instrumen pengumpulan data terdiri atas:

\section{Angket}

Penelitian ini memerlukan 4 jenis angket yaitu angket untuk ahli materi, angket untuk ahli media, angket untuk guru geografi SMA kelas X, dan angket untuk siswa SMA kelas $\mathrm{X}$. Angket untuk ahli materi digunakan untuk memperoleh data tentang aspek isi, aspek kebahasaan, aspek teknik penyajian, aspek kelengkapan media, dan aspek keterlaksanaan. Angket untuk ahli media digunakan untuk memperoleh data tentang aspek tampilan, aspek pemrograman, aspek tata letak isi, aspek tipografi, dan aspek ilustrasi. Angket untuk guru geografi SMA kelas X digunakan untuk memperoleh data tentang aspek isi, aspek pemrograman, aspek teknik penyajian, aspek kelengkapan media, dan aspek keterlaksanaan. Angket untuk siswa SMA kelas X digunakan untuk memperoleh data tentang aspek isi, aspek kebahasaan, aspek keterlaksanaan, aspek media, dan aspek ilustrasi.

2. Observasi
Observasi digunakan untuk analisis kebutuhan dalam pengembangan multimedia pembelajaran geografi berbentuk majalah elektronik.

\section{Tes Hasil Belajar}

Tes hasil belajar digunakan untuk melihat tingkat pencapaian hasil belajar pada kelas yang menggunakan multimedia pembelajaran berbentuk majalah elektronik. Bentuk tes yang digunakan dalam penelitian ini adalah bentuk tes pilihan ganda. Tes ini digunakan untuk menilai hasil belajar aspek kognitif. Perhitungan hasil belajar ini akan digunakan dalam penentuan keefektifan multimedia pembelajaran geografi berbentuk majalah elektronik.

\section{Teknik Analisis Data}

Data yang diperoleh dari hasil penelitian kemudian dianalisis secara deskriptif kuantitatif. Untuk menganalisis kelayakan multimedia pembelajaran geografi berbentuk majalah elektronik menggunakan penilaian dengan 5 kriteria kategori penilaian (Azwar, 2007, p. 163).

Tabel 1. Kategori Penilaian Kelayakan Majalah Elektronik

\begin{tabular}{clc}
\hline Nilai & \multicolumn{1}{c}{ Rentang Skor } & Kategori \\
\hline A & $M+1,50 \mathrm{~s}<\mathrm{X}$ & Sangat \\
& & Baik \\
B & $\mathrm{M}+0,50 \mathrm{~s}<\mathrm{X} \leq \mathrm{M}+1,50 \mathrm{~s}$ & Baik \\
$\mathrm{C}$ & $\mathrm{M}-0,50 \mathrm{~s}<\mathrm{X} \leq \mathrm{M}+0,50 \mathrm{~s}$ & Cukup \\
$\mathrm{D}$ & $\mathrm{M}-1,50 \mathrm{~s}<\mathrm{X} \leq \mathrm{M}-0,50 \mathrm{~s}$ & Kurang \\
E & $\mathrm{X} \leq \mathrm{M}-1,50 \mathrm{~s}$ & Sangat \\
& & Kurang \\
\hline
\end{tabular}

\section{Keterangan:}

$$
\begin{aligned}
& \mathrm{X}: \text { Skor rata- rata } \\
& \mathrm{M}: \text { Rata- rata ideal } \\
&: 1 / 2 \text { ( skor maksimal ideal }+ \text { skor } \\
& \text { minimal ideal) } \\
& \mathrm{S} \quad: \text { Simpangan baku } \\
&: 1 / 6 \text { (skor maksimal ideal }- \text { skor } \\
& \text { minimal ideal) }
\end{aligned}
$$

Skor maksimal ideal $=\Sigma$ indikator $\mathrm{x}$ skor tertinggi

Skor minimal ideal $=\Sigma$ indikator $\mathrm{x}$ skor terendah

Penelitian ini ditetapkan nilai kelayakan minimal "B", dengan kategori "Baik", sebagai hasil penilaian baik dari ahli media, ahli materi, guru geografi SMA kelas X, dan hasil uji coba terhadap siswa SMA kelas X. Jika 
penilaian akhir keseluruhan aspek dengan minimal "B" (Baik), maka produk hasil pengembangan tersebut sudah dianggap layak digunakan sebagai media atau sumber belajar.

Evaluasi sumatif dilakukan untuk mengetahui efektivitas produk berupa tingkat penguasaan kompetensi mata pelajaran yang diwujudkan dalam skor tes hasil belajar setelah menggunakan produk yang dikembangkan. Data pretest dan posttest hasil belajar dianalisis dengan membandingkan skor pretest dan posttest. Peningkatan yang terjadi sebelum kegiatan pembelajaran dengan menggunakan multimedia dan sesudah pembelajaran dengan menggunakan multimedia diperhitungkan dengan rumus gain score yang ditentukan berdasarkan average normalized gain (g) yaitu perbandingan dari gain score (Hake, 1998, p. 1)

$$
g=\frac{\% \boldsymbol{S} f-\% \boldsymbol{S i}}{\mathbf{1 0 0}-\% \boldsymbol{S i}}
$$

Keterangan

$\mathrm{g} \quad$ : average normalized gain

Sf : rata-rata nilai posttest

$\mathrm{Si} \quad$ : rata-rata nilai pretest

Hasil dari average normalized gain kemudian diinterpretasikan ke dalam tabel (g) klasifikasi nilai gain (Hake, 1998, p.2) dengan tiga klasifikasi yaitu jika average normalized gain lebih dari 0,70 maka termasuk kategori tinggi, jika average normalized gain 0,30 0,70 maka termasuk kategori sedang, dan jika average normalized gain kurang dari 0,30 maka termasuk kategori rendah.

\section{Hasil Penelitian dan Pembahasan}

Data yang diperoleh dari hasil validasi oleh ahli materi, ahli media dan guru geografi SMA kelas $\mathrm{X}$ dipergunakan untuk mengadakan revisi/perbaikan terhadap multimedia pembelajaran yang dikembangkan baik dari aspek materi dan aspek tampilan (media). Penilaian kualitas multimedia pembelajaran ditinjau dari aspek materi dan aspek tampilan (media) dapat dilihat pada Tabel 2, sebagai berikut:
Tabel 2. Kualitas Multimedia Pembelajaran Hasil Validasi oleh Ahli Materi, Ahli Media, dan Guru Geografi SMA kelas X.

\begin{tabular}{llcc}
\hline No. & Penilaian & $\begin{array}{c}\text { Rata-rata } \\
\text { Skor }\end{array}$ & Kriteria \\
\hline 1. & Ahli Materi & 20,8 & $\begin{array}{c}\text { Sangat } \\
\text { Baik }\end{array}$ \\
2 & Ahli Media & 15,5 & Baik \\
3 & Guru Geografi & 21,8 & $\begin{array}{c}\text { Sangat } \\
\text { SMa Kelas X }\end{array}$ \\
& Jumlah & 58,1 & Baik \\
& Rata-rata skor & 19,37 & Sangat \\
& & & Baik \\
\hline
\end{tabular}

Berdasarkan Tabel 2 menunjukkan bahwa kualitas multimedia pembelajaran dari penilaian ahli materi termasuk kriteria sangat baik dengan rata-rata skor 20,8, penilaian ahli media termasuk kriteria baik dengan rata-rata skor 15,5, dan penilaian guru geografi SMA kelas $\mathrm{X}$ termasuk kriteria sangat baik dengan rata-rata skor 21,8. Berdasarkan hasil tersebut maka kualitas multimedia pembelajaran ini termasuk kriteria sangat baik yaitu dengan rata-rata skor 19,37.

\section{Hasil Uji Coba Beta Test I}

Produk multimedia yang dikembangkan direvisi sesuai saran ahli meteri, ahli media, dan guru geografi SMA kelas $\mathrm{X}$, maka langkah berikutnya adalah uji coba beta test I. Uji coba beta test I dilakukan pada 7 siswa SMA Negeri 1 Pundong kelas $\mathrm{X}^{2}$.

Berdasarkan uji coba beta test I multimedia pembelajaran yang dikembangkan sudah baik. Skor yang diberikan oleh siswa SMA kelas $\mathrm{X}$ untuk aspek isi, aspek kebahasaan, aspek keterlaksanaan, aspek media, dan aspek ilustrasi dapat dilihat pada Tabel 3, berikut ini: 
Tabel 3. Hasil Analisis Data Uji Coba Beta Tes I oleh Siswa SMA Kelas X

\begin{tabular}{llcc}
\hline No & $\begin{array}{l}\text { Aspek yang di } \\
\text { Nilai }\end{array}$ & $\begin{array}{c}\text { Rata-rata } \\
\text { Skor }\end{array}$ & Kriteria \\
\hline 1 & Aspek Isi & 29,7 & Sangat \\
& & Baik \\
2 & Aspek & 20,4 & Sangat \\
& Kebahasaan & Baik \\
3 & Aspek & 25,9 & Sangat \\
& Keterlaksanaan & & Baik \\
4 & Aspek Media & 27,4 & Baik \\
5 & Aspek Ilustrasi & 13,7 & Sangat \\
& Jumlah & 117,1 & Baik \\
& Rata-rata Skor & 23,42 & Sangat \\
& & & Baik \\
\hline
\end{tabular}

Berdasarkan Tabel 3 menunjukkan bahwa multimedia pembelajaran dari hasil uji coba beta test $I$ termasuk kriteria sangat baik dengan rata-rata skor penilaian 23,42.

\section{Hasil Uji Coba Beta Test II}

Uji coba beta test II dilakukan pada 25 siswa SMA Negeri 1 Pundong kelas $\mathrm{X}^{2}$ di laboratorium komputer SMA Negeri 1 Pundong. Berdasarkan uji coba beta test II multimedia yang dikembangkan sudah baik. Skor yang diberikan oleh siswa SMA kelas X untuk aspek isi, aspek kebahasaan, aspek keterlaksanaan, aspek media, dan aspek ilustrasi dapat dilihat pada Tabel 4 , berikut ini:

Tabel 4. Hasil Analisis Data Uji Coba Beta Tes II oleh Siswa SMA Kelas X

\begin{tabular}{|c|c|c|c|}
\hline No & $\begin{array}{l}\text { Aspek yang di } \\
\text { Nilai }\end{array}$ & $\begin{array}{l}\text { Rata-rata } \\
\text { Skor }\end{array}$ & Kriteria \\
\hline 1 & Aspek Isi & 28,2 & $\begin{array}{l}\text { Sangat } \\
\text { Baik }\end{array}$ \\
\hline 2 & $\begin{array}{l}\text { Aspek } \\
\text { Kebahasaan }\end{array}$ & 20,4 & $\begin{array}{l}\text { Sangat } \\
\text { Baik }\end{array}$ \\
\hline 3 & $\begin{array}{l}\text { Aspek } \\
\text { Keterlaksanaan }\end{array}$ & 24,8 & $\begin{array}{l}\text { Sangat } \\
\text { Baik }\end{array}$ \\
\hline 4 & Aspek Media & 28 & Baik \\
\hline \multirow[t]{3}{*}{5} & Aspek Ilustrasi & 13,4 & $\begin{array}{l}\text { Sangat } \\
\text { Baik }\end{array}$ \\
\hline & Jumlah & 114,8 & \\
\hline & Rata-rata Skor & 22,96 & $\begin{array}{l}\text { Sangat } \\
\text { Baik }\end{array}$ \\
\hline
\end{tabular}

Berdasarkan Tabel 4 menunjukkan bahwa multimedia pembelajaran dari hasil uji coba beta test II termasuk kriteria sangat baik dengan rata-rata skor penilaian 22,96.

Efektivitas produk multimedia pembelajaran yang dikembangkan perlu dilakukan melalui evaluasi sumatif. Evaluasi sumatif diawali dengan menyelenggarakan pretest dan diakhiri dengan posttest. Berdasarkan analisis data evaluasi sumatif secara visual tampak pada gambar berikut:

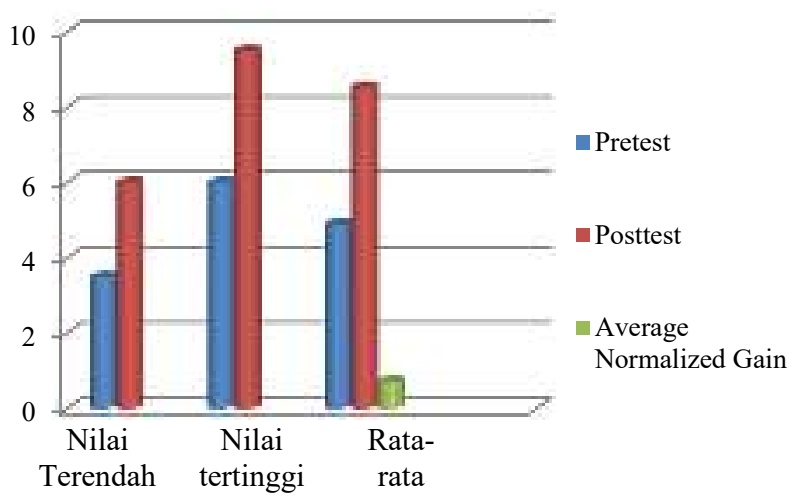

Gambar 1. Grafik Perbandingan Hasil Pretest dan Posttest Siswa SMA Kelas X SMA Negeri 1 Pundong

Data pada tampilan gambar tersebut dapat dijelaskan bahwa nilai terendah pretest sebesar 3,5 dan nilai tertinggi sebesar 6,0 . Rata-rata nilai sebesar 4,9. Setelah menggunakan multimedia pembelajaran dan diberikan posttest nilai terendah sebesar 6,0 dan nilai tertinggi sebesar 9,5 dengan jumlah rata-rata nilai sebesar 8,54. Peningkatan average normalized gain antara pretest dan posttest sebesar 0,72 dengan klasifikasi tinggi.

\section{Simpulan, Implikasi, dan Saran}

Simpulan

Multimedia pembelajaran geografi berbentuk majalah elektronik yang dikembangkan layak digunakan sebagai sumber belajar. Rata-rata skor penilaian kelayakan produk dari ahli materi sebesar 20,8 (sangat baik), ahli media sebesar 15,5 (baik), guru geografi SMA kelas X sebesar 21,8 (sangat baik), uji coba beta test I sebesar 23,42 (sangat baik), dan uji coba beta test II sebesar 22,96 (sangat baik).

Hasil belajar siswa pada saat pretest diperoleh rata-rata skor 4,90; sedangkan hasil belajar siswa pada posttest dan telah 
menggunakan multimedia pembelajaran sebagai sumber belajar diperoleh rata-rata skor 8,54. Berdasarkan hasil tersebut maka diperoleh average normalized gain 0,72 dan tergolong pada klasifikasi tinggi, maka dapat disimpulkan bahwa multimedia pembelajaran geografi berbentuk majalah elektronik dengan materi hidrosfer untuk siswa SMA kelas $\mathrm{X}$ yang dikembangkan efektif dan dapat meningkatkan penguasaan kompetensi mata pelajaran geografi.

Implikasi

Implikasi dari penelitian ini adalah jika multimedia pembelajaran geografi berbentuk majalah elektronik dengan materi hidrosfer digunakan sebagai sumber belajar baik di kelas atau mandiri, maka tingkat penguasaan siswa terhadap materi hidrosfer akan meningkat yang ditunjukkan dengan peningkatan hasil belajar.

\section{Saran Pemanfaatan Produk}

Beberapa saran untuk memanfaatkan multimedia pembelajaran ini adalah: (1) Membaca petunjuk penggunaan multimedia, (2) Produk multimedia pembelajaran dapat diimplementasikan dalam kegiatan pembelajaran mata pelajaran geografi SMA pada kompetensi dasar hidrosfer dan dampaknya terhadap kehidupan di muka bumi, dan (3) Pemanfaatan multimedia pembelajaran ini tidak terbatas pada kegiatan pembelajaran di kelas melainkan dapat dijadikan sumber belajar mandiri.

Pengembangan Produk Lebih Lanjut

Pengembangan produk lebih lanjut yaitu:

(1) Perlu diupayakan pengembangan teknik evaluasi yang mampu mengukur aspek afektif dan psikomotorik siswa setelah menggunakan produk multimedia pembelajaran ini, (2) Perlu diupayakan pengembangan multimedia pembelajaran dengan mengoptimalkan metode penyajian latihan soal dan evaluasi yang lebih bervariasi, (3) Perlu diupayakan pengembangan lebih lanjut dari segi kompetensi dasar dengan memperhatikan ketepatan materi dan rumusan tujuan pembelajaran sehingga lebih banyak materi yang di dapat dikembangkan sebagai sumber belajar mandiri siswa, dan (4) Pengembangan multimedia pembelajaran selanjutnya dikembangkan lebih bersifat dinamis dan disesuaikan dengan perkembangan teknologi software, hal tersebut dapat menarik dan memotivasi siswa dalam proses pembelajaran dengan multimedia.

\section{Daftar Pustaka}

Alessi, S. M. \& Trollip, S. R. (2001). Multimedia for learning: Methods and development (3rd ed.). Massachusetts: Ally \& Bacon A Pearson Education Company.

Azwar, Saifuddin. (2014). Tes prestasi:Fungsi dan pengembangan pengukuran prestasi belajar. Yogyakata: Pustaka Pelajar.

Daldjoeni. (2014). Pengantar geografi. Yogyakarta: Ombak.

Daryanto. (2010). Media pembelajaran peranannnya sangat penting dalam mencapai tujuan pembelajaran. Yogyakarta: Gava Media.

Gagne, R. M. \& Briggs L. M. (1979). Principles of instructional design $\left(2^{\text {nd }}\right.$ ed,). New York: Holt, Rinenart an Winston.

Hake, R.R. (1998). Interactive engagement methods in introductory mechanics courses. Departement of Physics, Indiana University, Bloomingtoon. Diambil pada tanggal 24 Agustus 2014, dari http://www.physics.indiana.edu.

Kingsley, K. V \& Boone, R. (2009). Effects of multimedia software on achievement of middle school students in an American History class. Journal of Research on Technology in Education Volume 41 Number 2.

Mayer, R. E. (2001). Multimedia learning. New York: Cambridge University Press.

Munir. (2013). Multimedia : Konsep \& aplikasi dalam pendidikan. Bandung: Alfabeta.

Murwantono, M \& Sukidjo, S. (2015). Peningkatan hasil belajar IPS dengan model problem based learning 
berbantuan media stimulan gambar. Harmoni Sosial: Jurnal Pendidikan IPS, 2(1), 30-41. Retrieved http://journal.uny.ac.id/index.php/hsipi/ article/view/4601.

Sumaatmadja, Nursid. (2001). Studi geografi suatu pendekatan dan analisa keruangan. Bandung: Alumni.

Sutopo, Ariesto Hadi. (2003). Multimedia interaktif dengan flash. Yogyakarta: Graha Ilmu.

\section{Profil Singkat}

Penulis

Dian Ardhina S.Pd. Kelahiran Bantul, 22 Juli 1989. Menempuh pendidikan Starata 1 pada jurusan Pendidikan Geografi Fakultas Ilmu Sosial Universitas Negeri Yogyakarta lulus pada tahun 2012, dan sedang menempuh pendidikan jenjang strata 2 pada jurusan Pendidikan Ilmu Pengetahuan Sosial Pascasarjana Universitas Negeri Yogyakarta.

Pembimbing

Dr. Mukminan. Kelahiran Purworejo, 06 September 1953. Sebagai dosen pada jurusan Pendidikan Geografi Fakultas Ilmu Sosial dan Program Studi Pendidikan Ilmu Pengetahuan Sosial Program Pascasarjana Universitas Negeri Yogyakarta. 